\title{
COMPETITIVENESS AND E-COMMERCE: AN EMPIRICAL STUDY ON MSMES PRODUCING TEMPE SANAN CHIPS IN MALANG CITY
}

\author{
${ }^{* 1}$ Mayasari, Chandra, ${ }^{2}$ Prasetyia, Ferry* \\ ${ }^{*}$ Universitas Brawijaya, designation, Faculty of Economic and Business, Malang, Indonesia \\ ${ }^{21}$ Universitas Brawijaya, designation, Faculty of Economic and Business, Malang, Indonesia \\ Note: * Indicates corresponding author
}

\begin{tabular}{|c|c|}
\hline ARTICLE DETAILS & \multirow{6}{*}{$\begin{array}{l}\text { ABSTRACT } \\
\text { This quantitative research was conducted to determine the effect } \\
\text { of e-commerce adoption on the competitiveness of MSMEs in } \\
\text { Tempe Sanan Chips Industry Center, Malang City. This study } \\
\text { used primary data obtained from questionnaires distributed to } \\
\text { respondents who were owners of the MSMEs in Sanan Tempe } \\
\text { Chips Industry Center who had adopted e-commerce. This study } \\
\text { used the Partial Least Square (PLS) method and employed } \\
\text { SmartPLS } 3.0 \text { as a tool. The results of the analysis showed that } \\
\text { the variable e-commerce adoption has a positive and significant } \\
\text { effect on MSME competitiveness; the control variables human } \\
\text { resources and business environment were found to have a } \\
\text { positive and significant effect on e-commerce adoption; the } \\
\text { control variables product innovation and product quality do not } \\
\text { have a positive and significant effect on e-commerce adoption; } \\
\text { the variables human resources, product innovation, and product } \\
\text { quality do not have a significant effect on MSME } \\
\text { competitiveness; and the control variable business environment } \\
\text { has a significant positive effect on MSME competitiveness. }\end{array}$} \\
\hline $\begin{array}{l}\text { Article History } \\
\text { Published Online: publisher use } \\
\text { only }\end{array}$ & \\
\hline Keywords & \\
\hline $\begin{array}{l}\text { MSME's, Partial Least Square, E- } \\
\text { commerce, SmartPLS, } \\
\text { Competitiveness }\end{array}$ & \\
\hline "Corresponding Author & \\
\hline Email:ferryfeub@yahoo.com & \\
\hline
\end{tabular}

\section{Introduction}

The development of Micro, Small, and Medium Enterprises dominates the business world in developing countries, including Indonesia. Their presence plays an important role in making the Indonesian economy even better, especially in creating jobs and reducing unemployment. In 2016, Indonesia had 62 million MSMEs or 98.68 percent of the total businesses of it (depkop.go.id).

Currently, according to the Central Statistics Agency (BPS) (2019), the challenges faced by MSMEs in Indonesia are the implementation of the ASEAN-China Free Trade Area (ACFTA) and the ASEAN Economic Community (AEC/MEA), causing their products to compete with imported products. To face these challenges, there are measures so that MSMEs can survive in free-market competition. This treatment can be done in two ways, namely

Faculty of Economics and Business,

Brawijaya University increasing the competitiveness of technologybased MSMEs in the digital era and assistance from the government to save the domestic MSMEs.

Increasing the competitiveness of technologybased MSMEs has been carried out by some MSMEs in Indonesia (Nyoman, 2017); technology and the internet are indispensable in expanding the MSME market. This is the biggest challenge so that MSMEs can continue to survive the industrial revolution 4.0.

BPS (2016) stated that only 6 percent of total MSMEs have used computers and the internet. Those who had used technology and

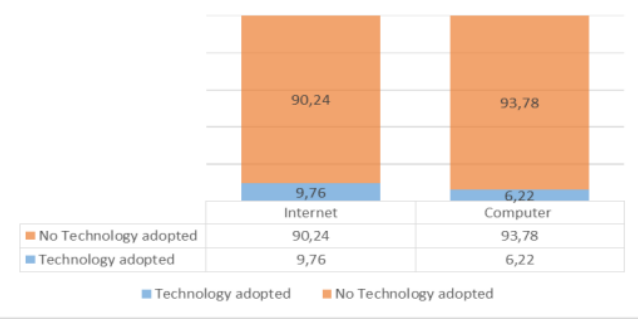




\section{COMPETITIVENESS AND E-COMMERCE: AN EMPIRICAL STUDY ON MSMES PRODUCING TEMPE SANAN CHIPS IN MALANG CITY}

computers had succeeded in increasing the performance, profit, and competitiveness of their companies. The extremely low utilization of the internet became a challenge for small businesses and governments in providing a competitive business environment. The following figure 1 presents data on the technology adopted by MSMEs, based on BPS data (2016):

Source : BPS, SE-2016 Lanjutan

According to studies of e-commerce adoption in developing countries in Indonesia, Malaysia, and Thailand by Nyoman (2017), Sin et al. (2016), and Wongpinunwatana (2003), the adoption of e-commerce in developing country MSMEs can have a significant effect on the performance and competitiveness of MSMEs. These three studies also showed that the use of technology in the company will lead to a more competitive business environment. According to research by Scupola (2009), the role of government is considered an important factor in increasing competitiveness in using technology.

Our research would discuss the analysis of e-commerce-based MSME competitiveness variables because studies that discuss the relationship between MSME competitiveness and e-commerce adoption were still rare. Research by Fitanto (2001), Wayne (2014), and Elbeltagi (2016) discussed the adoption of ecommerce for MSMEs but was not specifically related to competitiveness. With this our research, it was hoped that we could find out whether or not the adoption of e-commerce can affect the competitiveness of Tempe Sanan chips industry center or whether or not other factors influence it based on Porter's Diamond Model in calculating competitiveness. Therefore, research with the title "Analysis of ECommerce Based MSME Competitiveness Variables: A Case Study of Tempe Sanan Chips Industry Center in Malang" needed to be done.

\section{Literature Review}

\section{Porter's Diamond Model}

According to Porter, a country will gain a competitive advantage if companies in it are competitive in doing business. A company can be said to have competitive competitiveness if it is under pressure from other companies. That pressure will make companies try to innovate and make it more competitive. Based on this

Faculty of Economics and Business,

Brawijaya University idea, Porter created a model called the Diamond Model to measure the competitiveness of a country, : Chance JW.

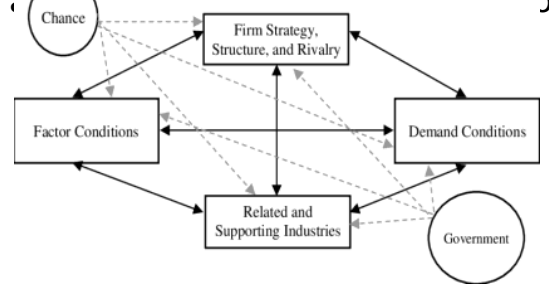

Source : Porter, M (1985)

In this Diamond Model, four factors, namely company strategy, demand conditions, supporting companies, and factor conditions, form competitiveness. Apart from these four factors, some opportunities, and the Government, do not directly affect competitiveness. The main point of Porter's Diamond Model's thinking is that Porter wants to create self-informing competitiveness, where domestic competition can positively affect the growth of industry and form advanced consumers. Consumers who are advanced and always want improvement and innovation can make companies motivated to innovate and increase competitiveness.

\section{E-Commerce Stage Model}

There are several stages in adopting ecommerce. According to (Rao, 2003) there are 4 stages in the use of e-commerce, namely Presence Stage, Portals Stage, Transaction Integration Stage, and Enterprises Integration Stage, all of which have different characteristics from one another. The following figure 3 is the stage model in adopting e-commerce:

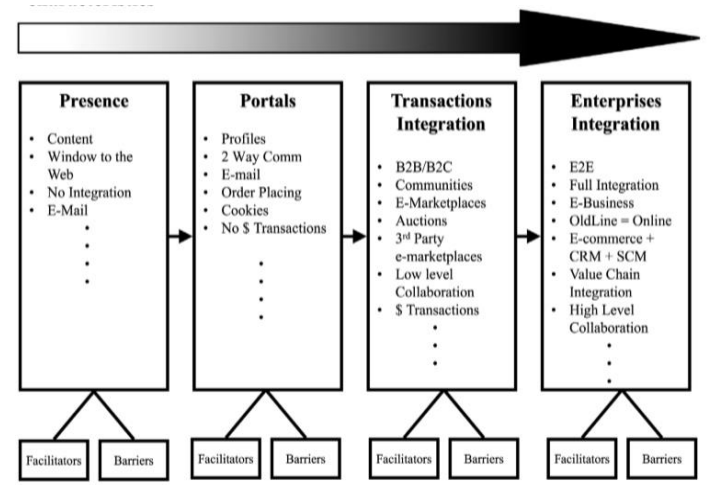

Figure 3. Chart 01 E-Commerce Stage Model Source: Rao (2003)

Presence Stage is the initial stage of a company or organization in having access to develop its business through the website. Portal 
Stage is when the company starts to open facilities for customers to order goods. Transaction Integration Stage is a stage where 2-way communication between the company and customers is getting stronger. Its most prominent characteristic is in the detailed ordering process and that customers are free to see product choices in the form of a catalog and price of goods. Enterprises Integration has a characteristic where companies can integrate business-to-business (B2B) relationships and business-to-customers (B2C).

\section{Previous Studies}

Research by Mazzarol (2015) suggested the importance of adopting e-commerce for MSMEs; although it is difficult to implement, it is worth trying to improve the company's performance and competitiveness. In addition to research that conveyed the importance of $e$ commerce adoption, other findings strengthened this opinion.

According to Hamad (2018), adopting ecommerce can increase competitiveness globally; in Egypt, technological, organizational, and environmental factors would significantly influence the adoption of e-commerce in MSMEs. This statement was refuted by research by $\operatorname{Sin}$ et al. (2016) who argued that relative advantage has more influence on the variable ecommerce adoption for case studies in Malaysia. These statements triggered a debate whether or not the adoption of e-commerce by MSMEs can indeed increase the competitiveness.

The increasing competitiveness of MSMEs after adopting e-commerce was proven by the research of Handarkho et al. (2017). Their research stated that MSMEs had increased competitiveness because they could continue to innovate according to customer interests through the adoption of e-commerce. In research by Fitanto (2009) at the MSMEs of Mojokerto Shoe Cluster, it was stated that always doing innovation means increasing competitiveness. In this research, we would discuss the analysis of factors that affect the competitiveness of e-commerce-based MSMEs.

\section{Methods}

The data used in this study were obtained through surveys and questionnaires to the Tempe Sanan Chips Industry Center, Malang City, namely 50 MSMEs that have adopted ecommerce, in 2020. The sampling technique in this study used purposive sampling; only

Faculty of Economics and Business,

Brawijaya University
MSMEs that had adopted e-commerce were studied. Data were processed using SmartPLS 3.0 and Microsoft Excel software.

The data analysis method used in this study was the Partial Least Square (PLS) method. There were two lines of the structural equation used in this study, namely, first, the adoption of e-commerce as the first dependent variable and, secondly, competitiveness as the second dependent variable. The following is the mathematical model used: i. $\quad \mathrm{Y}=\mathrm{pyx}_{1} \mathrm{X} 1+\mathrm{pyx}_{2} \mathrm{X} 2+\mathrm{pyx}_{3} \mathrm{X} 3+$ pyx $_{4} \mathrm{X} 4+\varepsilon 1$

$$
\begin{aligned}
& \text { ii. } Z=\mathrm{pzx}_{1} \mathrm{X} 1+\mathrm{pzx}_{2} \mathrm{X} 2+\mathrm{pzx}_{3} \mathrm{X} 3+ \\
& \text { pzx }_{4} \mathrm{X} 4+\mathrm{pzY}+\varepsilon 2
\end{aligned}
$$

Note:

$\mathrm{Y}=\mathrm{E}$-Commerce adoption

$Z$ = Competitiveness

$\mathrm{X} 1=$ Human resource

$\mathrm{X} 2$ = Product innovation

$\mathrm{X} 3=$ Product quality

$\mathrm{X} 4$ = Business environment

$\varepsilon=$ Error Term

\section{Findings}

\section{Variable Description}

The description of variables in the descriptive statistics used in this study includes the characteristics of the respondents based on gender, age, education, length of business, and length of business using e-commerce. The characteristics of the research variables include four independent variables, namely human resources, product innovation, product quality, and business environment, one intervening variable e-commerce adoption, and one dependent variable competitiveness. 


\section{COMPETITIVENESS AND E-COMMERCE: AN EMPIRICAL STUDY ON MSMES PRODUCING TEMPE SANAN CHIPS IN MALANG CITY}

Reliability. The value of Cronbach Alpha and Composite Reliability must be more than 0.6 so that the variables in the study are reliable.

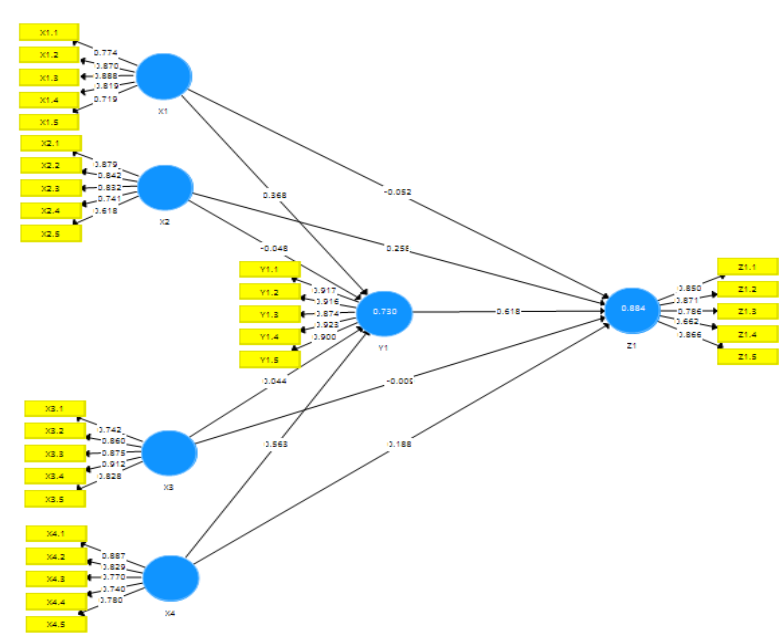

Figure 4.

The first step used in research using SmartPLS is testing the measurement model, which is done by looking at the factor loading so that it meets convergent validity. If the factor loading value is $>0.70$, then the research indicators can be processed and produce the output in the following figure above.

Figure 4 shows that the factor loading on the data is valid $(>0.7)$. The results of the outer model show the results of testing the reliability and validity of each variable.

\section{a. Factor Loading}

Factor loading is useful for assessing whether or not a construct has sufficient discriminant validity by comparing the correlation of indicators between constructs with each other. Figure 4 shows that the indicators of each construct give a high convergent validity value.

\section{b. Descriminant Validity}

Descriminant validity can be seen from the Average Variance Extracted (AVE), which must be more than 0.5 to state that each item of the questionnaire question is said to be valid. In this study, the AVE value was above 0.5 for each variable.

\section{c. Composite Reliability}

The reliability test in PLS can be seen from the Cronbach Alpha value and Composite

Faculty of Economics and Business,

Brawijaya University

\begin{tabular}{|l|l|l|l|l|}
\hline \multicolumn{1}{|c|}{ Variable } & \multicolumn{1}{|c|}{$\begin{array}{c}\text { Cronbach's } \\
\text { Alpha }\end{array}$} & \multicolumn{1}{c|}{$\begin{array}{c}\text { Composite } \\
\text { Reliability }\end{array}$} & $\begin{array}{c}\text { Cut } \\
\text { offt }\end{array}$ & Information \\
\hline Human Resource (X1) & 0.874 & 0.909 & 0.6 & Valid \\
\hline Product Innovation (X2) & 0.843 & 0.890 & 0.6 & Valid \\
\hline Product Quallity (X3) & 0.907 & 0.926 & 0.6 & Valid \\
\hline $\begin{array}{l}\text { Business Environment } \\
\text { (X4) }\end{array}$ & 0.861 & 0.900 & 0.6 & Valid \\
\hline $\begin{array}{l}\text { E-commerce Adoption } \\
\text { (Y1) }\end{array}$ & 0.945 & 0.958 & 0.6 & Valid \\
\hline Competitiveness (Z1) & 0.868 & 0.905 & 0.6 & Valid \\
\hline
\end{tabular}

\section{Table 1 Reliability Testing}

After fulfilling all the criteria for the outer model, testing the structural model (inner model) was carried out. The inner model was evaluated by looking at the percentage variance described in the R-Square. The $R$-Square value was obtained at 0.730 . This value explained that the percentage of the level of e-commerce adoption could be explained by the variables of human resources, product innovation, product quality, and business environment by $73 \%$. The $R$ Square value for the variable competitiveness of 0.884 explained that the variable competitiveness influences the variables human resources, product innovation, product quality, business environment, and e-commerce adoption by $88.4 \%$. Besides $R$-Square, model evaluation could also be done by looking at $Q^{2}$ as follows:

$$
\begin{aligned}
& \text { Q-Square }=1-\left[\left(1-R^{2} 1\right) \times\left(1-R^{2}\right)\right] \\
& =1-[(1-0,730) \times(1-0,884)] \\
& =0.96868
\end{aligned}
$$

The value of $Q 2$ was $0.96868>0$, meaning that the research model has a predictive relevance value: the closer to 1 , the better the model.

The next stage was hypothesis testing based on processing research data using SmartPLS with the boostrap resampling method. The results 
would be obtained from the $t$-statistic value and would be compared to the $t$-table: if the $t$-statistic value is greater than the $t$-table value, the proposed research hypothesis is accepted, and vice versa. The confidence level used was $95 \%$ so that $\lambda=5 \%$ with a $t$-table value of 2.42 so that:

1. If the $t$-statistic value is smaller than the $t$-table value $<2.42$, then the hypothesis is rejected.

2. If the $t$-statistic value is greater than or equal to the $t$-table> 2.42, then the hypothesis is accepted.

Hypothesis testing for the outer model was done by looking at the $t$-statistic indicators. The following are the results of hypothesis testing:

Table 2 hypothesis testing

\begin{tabular}{|l|l|l|l|l|l|}
\hline \multicolumn{2}{|c|}{ Hypothesis } & Coefficient & $\begin{array}{c}\text { t- } \\
\text { statistic }\end{array}$ & $\begin{array}{c}p \text { - } \\
\text { value }\end{array}$ & Information \\
\hline H1 & $\begin{array}{l}\text { E-commerce Adoption } \rightarrow \\
\text { Competitiveness }\end{array}$ & 0.618 & 7.180 & 0.000 & Significant \\
\hline & $\begin{array}{l}\text { Human Resource } \rightarrow \\
\text { E-commerce Adoption }\end{array}$ & 0.368 & 2.422 & 0.049 & Significant \\
\hline Human Resource $\rightarrow$ Competitiveness & -0.052 & 1.217 & 0.224 & Insignificant \\
\hline & $\begin{array}{l}\text { Product Innovation } \rightarrow \\
\text { E-commerce Adoption }\end{array}$ & -0.048 & 0.379 & 0.705 & Insignificant \\
\hline $\begin{array}{l}\text { Product Innovation } \rightarrow \\
\text { Competitiveness }\end{array}$ & 0.258 & 1.727 & 0.085 & Insignificant \\
\hline & $\begin{array}{l}\text { Product Quality } \rightarrow \\
\text { E-commerce Adoption }\end{array}$ & 0.044 & 0.398 & 0.691 & Insignificant \\
\hline Product Quality $\rightarrow$ Competitiveness & -0.008 & 0.205 & 0.838 & Insignificant \\
\hline & $\begin{array}{l}\text { Business Environment } \rightarrow \\
\text { E-commerce Adoption }\end{array}$ & 0.568 & 3.386 & 0.001 & Significant \\
\hline & $\begin{array}{l}\text { Business Environment } \rightarrow \\
\text { Competitiveness }\end{array}$ & 0.188 & 3.890 & 0.000 & Significant \\
\hline
\end{tabular}

Source : Author

1. The variable e-commerce adoption has a significant effect on the competitiveness of MSMEs because the $t$-statistic value is $>t$-table with a $t$-statistic value of 7.180 . The results obtained by researchers were in line with the results of research by Tambunan (2014), which stated that the main driver in increasing company competitiveness is human resources, including human resource education, capital, technology, and information. By adopting ecommerce, many of the MSMEs in Sanan had increased their turnover and income. The average use of e-commerce that had been running was in the form of promotion through ecommerce and via social media WhatsApp, Facebook, and Instagram. MSME owners admitted that since using e-commerce services, they often had been getting orders from outside the city.

2. The variable human resource has a significant influence on the variable e-commerce adoption with a $t$-statistic value of 2.422 and a $P$-value of 0.049. According to Tambunan (2014),

Faculty of Economics and Business,

Brawijaya University indicators of company competitiveness are profit, human resources, and types of technology. Besides, the main driver in increasing company competitiveness is human resources, including their education or skills in understanding how e-commerce works and its application. In this study, a significant positive result occurred, possibly because most of the MSME owners who had adopted e-commerce preferred employees who understand how to apply e-commerce rather than those who do not, to make it easier for MSMEs to market their products online without problems, to be better known and increase their profits.

3. The variable product innovation has no significant effect on e-commerce adoption because the $t$-statistic value is $<t$-table with a $t$ statistic value of 0.379 . According to research by Nyoman (2017), being an important indicator in the marketing performance of MSMEs, product innovation, however, is not a variable that affects e-commerce adoption. This is because the product innovation carried out by an MSME does not consider customer interest and demand due to limited technology for processing products.

4. The variable product quality has no significant effect on e-commerce adoption because the $t$ statistic value is $>t$-table with a $t$-statistic value of 0.398 . Because the $P$-value is 0.691 , more than 0.5 , the product quality variable on e-commerce adoption is declared insignificant. This is because the objects of research at the Tempe Sanan Chips Industry Center tended to not differentiate the quality of the products sold in nearby shops or those sent via expedition or packages. The absence of special handling to maintain good product quality until it reaches customers who buy through e-commerce is the possible cause of the insignificance of this variable on e-commerce adoption.

5. The variable business environment has a significant influence on the e-commerce adoption variable with a $t$-statistic value of 3.386 and a $P$-value of 0.001 . According to Mazarol (2015), business environment has a significant influence on e-commerce adoption because the provision of adequate infrastructure for the development of MSMEs is needed. Besides, the roles of MSME owners and managers are also needed to create business strategies based on digital technology. The significant results in this study are probably due to the city government of Malang that helps to develop this industrial center through, one of which, providing assistance and grants to fund the development of MSMEs in Sanan and holding e-commerce training for employees employed at these 


\section{COMPETITIVENESS AND E-COMMERCE: AN EMPIRICAL STUDY ON MSMES PRODUCING TEMPE SANAN CHIPS IN MALANG CITY}

MSMEs. Many of these employees took ecommerce training and had a positive impact on increasing competitiveness through product marketing in e-commerce.

\section{Conclusions}

Based on the research results, the following conclusions can be drawn:

1. The variable e-commerce adoption has a positive and significant effect on the competitiveness of MSMEs in the Sanan Tempe Chips Industry Center. Thus the hypothesis in the study can be accepted.

2. E-commerce adoption can help several MSMEs in the Sanan Industrial Center to compete and cooperate with large companies.

3. E-commerce adoption by MSMEs can expand the reach of product marketing to all regions and can increase sales and turnover.

4. E-commerce is considered as one of business aspect which can create/give value added of product in competitive market.

The limitations in this study were as follows:

1. In its implementation, this research was only conducted in 50 MSMEs in the Tempe Sanan Chips Industry Center which had adopted e-commerce, thus not provide information on the overall competitiveness of MSMEs in Malang City area optimally.

2. This research used questionnaires so that the data collected only described the opinions of MSME actors on ecommerce adoption and MSME competitiveness. Besides, this research also ignored the influence of other MSMEs that did not adopt e-commerce but also contributed to the competitiveness of the Industry Center.

3. This study used the PLS method which had weaknesses, including the unknown distribution of the data so that it had a bias value, and was not normal.

\section{References}

Awiagah, K. . 2016. Factor's Affecting ECommerce Adoption Among SME's in Ghana. Journal Information Development , 1-22.

Faculty of Economics and Business,

Brawijaya University
Badan Pusat Statistik .2019. ANALISIS HASIL SE2016 LANJUTAN POTENSI PENINGKATAN KINERJA USAHA MIKRO KECIL. Jakarta: Badan Pusat Statistik.

Elbeltagi, H. M.-S. 2016. Levels of Business to Business E-Commerce Adoption and Competitive Advantage in Small Medium Sized Enterprises : A Comparasion Study Between Egypt and United States. Journal of Global Information Technology Management, 6-25.

Fitanto, B. 2001. Analisis Omset dan Posisi Bersaing Pada Klaster Usaha Kecil Menengah (UKM) Sepatu di Mojokerto. Journal of Indonesian Applied Economics , 23-36.

Gautam Ray, J. B. 2004. Capabilities, Business Processes and Competitive Advantage : Choosing the Dependent Variable In Empirical Test of the Resource Based View. Strategic Management Journal WIley Interscience , 23-37.

Ghobakhloo, A. A. 2011. Adoption of ECommerce Applications in SMEs. Journal Industrial Management and Data Systems , 1238-1269.

Ghozali, I. 2016. Aplikasi Analisis Multivariete Dengan Program IBM SPSS 23. Semarang: Badan Penerbit Universitas Diponegoro.

Hamad, E. . 2018. An Empirical Investigation of Business to Business E-Commerce Adoption and Its Impact on SMEs Competitive Advantage : The Case of Egyptian Manufacturing SMEs. Journal Strategic Change Research Gate , 209229.

Handarkho. 2017. Penerapan Strategi EBusiness Untuk Meningkatkan Keunggulan Kompetitif dari Usaha Mikro Menengah di Yogyakarta. Jurnal Buana Informatika .

I Gede Nyoman Mindra Jaya, I. M. 2008. PEMODELAN PERSAMAAN STRUKTURAL DENGAN PARTIAL LEAST SQUARE . Semnas Matematika dan Pendidikan Matematika 2008 118-132. 
Idris Abdulhakeem. 2017. E-Commerce Adoption in Developing Countries SME's : What Do the Prevailing Theoretical Models Offer Us? International Conference on E-Commerce by Faculty of Computer Science, University of Sunderland United KIngdom , 20-28.

Imam, G. 2014. Structural Equation Modeling Metode Alternatif dengan Partial Least Square (PLS). Semarang: Universitas Diponegoro.

Kaynak. 2014. An Analysis of the Factor Affecting the Adoption of Electronic Commerce by Small Medium Enterprises. Journal Enterprise Information Management , 623-640.

Kit Yeng Sin, A. O. 2016. Relative Advantage and Competitive Pressure Towards Implementation of E-Commerce Overview of Small Medium Enterprises. Science Direct , 434-443.

Ngunyen, T. X. 2019. Research on the Application of E-Commerce to Small and Medium Enterprises (SMEs) : Case of India. Journal Business and Economics Research Macrothink Institute , 102113.

Nyoman, Y. 2017. Pengaruh Inovasi, Adopsi Ecommerce, dan Keunggulan Kompetitif Terhadap Kinerja Pemasaran. Jurnal Manajemen, Fakultas Ekonomi dan Bisnis Universitas Udayana, Kampus Bukit Jimbaran, Indonesia , 347-358.

Pedro Soto Acosta, S. P. 2015. E-Business, Organizational Innovation and Firm Performance In Manufacturing SMEs: An Empirical Study in Spain. Journal Technological and Economic Development of Economy University Sydney Library , 20-28.

Plant, R. T. 2000. E-Commerce Formulation of Strategy.

Porter, M. 1985. COMPETITIVE ADVANTAGE. New York \& Ontario: Maxwell Macmillan Canada, Inc.
Ramanathan. 2012. The Impact of E-Commerce on Taiwanese Small Medium Enterprises : Marketing and Operations Effects. International Journal of Production Economics Research Gate , 934-943.

Ramdani, S. N. 2016. Strategi Pengembangan UKM Digital Dalam Menghadapi Era Pasar Bebas. Jurnal Manajemen Indonesia , 136-147.

Rui Bi, R. D. 2016. E-Business and Fast Growth SMEs. Journal of Springer Science and Business Media New York , 1-18.

S Pavic, M. S. 2007. Could E-Business Create a Competitive Advantage in United Kingdom SME's. International Journal Emerald Group Publishing , 320-351.

Scupola. 2009. Small Medium Enterprises Ecommerce Adoption : Perspective from Denmark and Australia. Journal of Enterprise Information Management, 152-166.

Tambunan, T. 2014. Ukuran Daya Saing Koperasi dan UKM. Jurnal Univeristas Trisakti, Pusat Studi Industri UKM , 1-30.

Tim, M. 2015. Small Medium Enterprise's Engagement with E-Commerce, EBusiness and E-Marketing. Small Enterprise Research , 1-12.

Wayne, P. 2014. E-Commerce and Small Medium Enterprises in Regional Communities. Research Gate , 1-9.

Wiyadi. 2009. Pengukuran Indeks Daya Saing Industri Kecil Menengah (IKM) di Jawa Tengah. Jurnal Siasat Bisnis Vol.13 No.1, 77-92.

Wongpinunwata, L. 2003. E-Commerce Adoption in Thailand : An Empirical Study of Small Medium Enterprises (SMEs). Journal of Global Information Technology Management , 67-83. 